\title{
Variability of Phenotype in Two Sisters with Pyridoxine Dependent Epilepsy
}

\author{
Majid Alfadhel, Sandra Sirrs, Paula J. Waters, András Szeitz, Eduard Struys, \\ Marion Coulter-Mackie, Sylvia Stockler-Ipsiroglu
}

\begin{abstract}
Background: Pyridoxine dependent epilepsy (PDE) is characterized by neonatal epileptic encepahalopathy responsive to pharmacological doses of vitamin $\mathrm{B}_{6}$. Recently an autosomal recessive deficiency in Antiquitin (ALDH7Al), a gene involved in the catabolism of lysine has been identified as the underlying cause. Case report: In 21 and 23 year-old sisters, who had presented with neonatal / early infantile onset seizures, PDE was confirmed by elevated urinary alpha aminoadipic- 6- semialdehyde ( $\alpha$-AASA) excretion and compound heterozygosity for two known ALDH7Al missense mutations. Although epilepsy was well controlled upon treatment with pyridoxine, thiamine, phenytoin and carbamazepine since early infancy, both had developmental delay with prominent speech delay as children. As adults, despite the same genetic background and early treatment with pyridoxine, their degree of intellectual disability ( ID ) differed widely. While the older sister's cognitive functions were in the moderate ID range and she was not able to live unattended, the younger sister had only mild ID and was able to live independently. Conclusion: Although seizures are a defining feature of PDE, other disease manifestations can vary widely even within the same family. Adult neurologists should be aware that the diagnosis of PDE can be delayed and PDE should be considered in the differential diagnosis of adults with seizure disorders dating from childhood.
\end{abstract}

RÉSUMÉ: Variabilité du phénotype chez deux sœurs atteintes d'épilepsie pyridoxino-dépendante. Contexte : L'épilepsie pyridoxino- dépendante (EPD) est caractérisée par une encéphalopathie épileptique néonatale qui répond à des doses pharmacologiques de vitamine B6. Un déficit en antiquitine (ALDH7A1), une maladie récessive autosomique due à un gène impliqué dans le catabolisme de la lysine, a été identifié comme étant la cause de cette maladie. Observation clinique : L'EPD a été confirmée par une excrétion urinaire élevée d'alpha aminoadipic-6-semialdéhyde ( $\alpha$-AASA) chez deux sœurs, âgées respectivement de 21 ans et 23 ans, qui avaient présenté des crises épileptiques en période néonatale ou tôt dans l'enfance. Toutes deux sont porteuses d'une hétérozygotie composée de deux mutations faux-sens connues du gène ALDH7A1. Bien que l'épilepsie ait été bien contrôlée par le traitement à la pyridoxine, à la thiamine, à la phénytoïne et à la carbamazépine administrées tôt dans l'enfance, les deux sœurs présentaient un retard du développement ainsi qu'un retard évident du langage dans l'enfance. Malgré un bagage génétique semblable et un traitement précoce par la pyridoxine, leur niveau de déficit intellectuel (DI) diffère grandement à l'âge adulte. Les fonctions cognitives de l'aînée se situent au niveau d'un DI modéré et elle ne peut pas vivre de façon autonome. Par contre, la plus jeune n'a qu'un léger DI et elle est capable de vivre de façon autonome. Conclusion : Bien que les crises épileptiques soient une caractéristique déterminante de l'EPD, les autres manifestations de la maladie peuvent varier grandement même au sein d'une même famille. Les neurologues qui traitent des patients adultes devraient garder en mémoire que le diagnostic d'EPD n'est pas toujours fait tôt dans la vie. Chez les adultes qui présentent un trouble convulsif ayant débuté dans l'enfance, l'EPD devrait donc faire partie du diagnostic différentiel.

Can J Neurol Sci. 2012; 39: 516-519

Pyridoxine dependent epilepsy (PDE) (MIM\#266100) is an autosomal recessive epileptic encephalopathy characterised by a therapeutic response to vitamin $\mathrm{B}_{6}$. Recently, deficiency in Antiquitin, a protein involved in the catabolism of lysine encoded by the ALDH7Al gene has been identified as the underlying genetic cause. ${ }^{1}$ Antiquitin (ATQ) deficiency results in accumulation of $\alpha$-amino adipic semialdehyde (AASA) and pipecolic acid, which serve as diagnostic markers in urine and plasma. The clinical presentation of PDE ranges from neonatal / early infantile epileptic encephalopathy to seizure onset at up to three years of life ${ }^{2-4}$, autism, and partial response to common anticonvulsants. ${ }^{5}$ Little is known about the intra-familial clinical heterogeneity and outcomes in adulthood. We describe two adult sisters with different degrees of intellectual disability despite seizure control since early infancy.
From the Division of Biochemical Diseases (MA, MCM, SSI), Department of Paediatrics, BC Children's and Women's Hospital; Adult Metabolic Diseases Clinic (SS), Division of Endocrinology, Department of Medicine, Vancouver Hospital and Health Sciences Centre; Biochemical Genetics Laboratory (PJW), Department of Pathology, Faculty of Pharmaceutical Sciences (AS), University of British Columbia, Vancouver, British Columbia; Service de Génétique Médicale (PJW), Département de Pédiatrie, Université de Sherbrooke, Quebec, Canada; VU University Medical Centre (ES), Metabolic Unit, Department of Clinical Chemistry, Amsterdam, Netherlands; Division of Genetics (MA), Department of Pediatrics, King Saud bin Abdulaziz University for Health Sciences, King Abdulaziz Medical City, Riyadh, Saudi Arabia. Received October 31, 2011. Final Revisions Submitted January 18, 2012. Correspondence to: Majid Alfadhel, Division of Genetics, Department of Pediatrics, King Saud bin Abdulaziz University for Health Sciences, King Abdulaziz Medical City, Riyadh, Saudi Arabia, P.O. Box: 22490 Riyadh 11426.

Email: dralfadhel@yahoo.com 


\section{CASe Report}

Patient 1: was born to non-consanguineous Caucasian parents, by emergency $\mathrm{C}$-section due to fetal deceleration. Her birth weight was $3.9 \mathrm{~kg}$ (75th centile) and the head circumference was $35 \mathrm{~cm}$ (50th centile). Apgar scores were 9 and 9 at one and five minutes. At 30 hours of life she had a generalized tonic- clonic status epilepticus with burst suppression pattern, along with high blood lactate concentrations (5.2 mmol/1; normal < 2.5). Seizures were unresponsive to phenytoin and phenobarbital. Seizures stopped clinically and electroencephalographically after intravenous pyridoxine $(100 \mathrm{mg})$ and thiamine (100 mg) administration and blood lactate concentrations normalized. Pyridoxine was given according to routine protocol in cases with pharmacologically intractable epilepsy. Thiamine was given because pyruvate dehydrogenase (E1) deficiency, which is responsive to pharmacological dosages of thiamine, was considered as one possible differential diagnosis of lactic acidemia. Computed tomography (CT) scan was normal. Treatment was continued with pyridoxine and thiamine, as well as carbamazepine and phenytoin throughout adulthood. Her psychomotor development including speech was delayed (Table). She remained seizure free until the age of 19 years when seizures recurred but seizure control was regained when her medication doses were adjusted for her weight. Currently she is maintained on pyridoxine $400 \mathrm{mg}$, phenytoin $300 \mathrm{mg}$ once daily, and carbamazepine $400 \mathrm{mg}$ in the morning and $500 \mathrm{mg}$ in the evening.

At the age of 23 years she has decreased muscle tone with reflexes +1 , and a wide based gait on neurological examination. She rocks back and forth while sitting and shakes/flaps her hands frequently. Her demeanor is friendly and cooperative. System examination is unremarkable. Her cognitive and adaptive skills are within the moderate intellectual disability (ID) range (details see Table).

Patient 2 : was born by $\mathrm{C}$-section at term due to previous $\mathrm{C}$ section. Her initial weight was $3.2 \mathrm{~kg}$ (50th centile) and the head circumference was $35 \mathrm{~cm}$ (50th centile). Apgar scores were 9, 9 at 1 and 5 minutes. She was seizure-free until the age of six

Table: Developmental milestones and functioning and behaviour in two 23 and 21 year old sisters with pyridoxine dependent epilepsy due to Antiquitin deficiency

\begin{tabular}{|c|c|c|}
\hline Development & Patient1 & Patient2 \\
\hline $\mathrm{IQ}$ & $\begin{array}{l}\text { Age } 10 \text { years: } \\
\text { Not able to complete tasks on age appropriate standardized } \\
\text { test batteries. } \\
\text { Estimated (not standardized) full scale IQ }=35-55^{1} \\
\text { Equals functioning at a developmental age of } \\
\text { 3.5-years. }\end{array}$ & $\begin{array}{l}\text { Non verbal IQ }=77-89 \\
\text { verbal } I Q=62-74 \\
\text { full scale } I Q=70-78^{2} \\
\text { Equals functioning at a developmental age of } \\
8 \text { years } 11 \text { months. }\end{array}$ \\
\hline $\begin{array}{l}\text { Degree of } \\
\text { intellectual } \\
\text { disability }\end{array}$ & Moderate & Mild \\
\hline $\begin{array}{l}\text { Motor } \\
\text { development }\end{array}$ & $\begin{array}{l}\text { Sitting: } 18 \text { months } \\
\text { Walking: } 3 \text { years }\end{array}$ & $\begin{array}{l}\text { Acquired motor milestones: } \\
\text { age appropriate }\end{array}$ \\
\hline $\begin{array}{l}\text { Speech } \\
\text { development }\end{array}$ & $\begin{array}{l}\text { First words: } 4 \text { years. } \\
\text { Currently (age23y): } \\
\text { Expressive and receptive language difficulties: } \\
\text { especially with regard to memory and comprehension of } \\
\text { language. } \\
\text { Uses small } 3 \text { to } 5 \text { word sentences and may need to ask her } \\
\text { many questions in various ways to express herself verbally. } \\
\text { Verbal and non-verbal response to order after extended pause. }\end{array}$ & $\begin{array}{l}\text { First words: } 3 \text { years. } \\
\text { Currently (age21y): } \\
\text { Expressive and receptive language: } \\
\text { Communicates with long sentences, able to tell } \\
\text { stories and describe her needs. }\end{array}$ \\
\hline School & $\begin{array}{l}\text { Completed grade } 12 \text { with an assisted curriculum } \\
\text { Able to read at a grade } 2 \text { level and do some basic mathematics }\end{array}$ & $\begin{array}{l}\text { She is able to read } \\
\text { Completed grade } 12 \text { with an assisted curriculum }\end{array}$ \\
\hline $\begin{array}{l}\text { Day to day } \\
\text { functioning }\end{array}$ & $\begin{array}{l}\text { Not able to live unassisted. She needs to be told when to have } \\
\text { a shower, when to get up, when to go to bed, when to brush } \\
\text { her teeth, when it's time to eat. } \\
\text { She is able to heat up a cup of coffee, make a sandwich, and } \\
\text { pour herself something to drink. }\end{array}$ & $\begin{array}{l}\text { Meets her own needs for food, sleep, medication } \\
\text { Living independently in her own apartment. } \\
\text { Working as assistant in a kennel. }\end{array}$ \\
\hline $\begin{array}{l}\text { Behavior, social } \\
\text { environment }\end{array}$ & $\begin{array}{l}\text { Rock back and forth while sitting and shake/flap her hands } \\
\text { frequently. Lives with parents; friendly and cooperative }\end{array}$ & $\begin{array}{l}\text { Maintains friendly relationships to peers; } \\
\text { Has a boy friend. }\end{array}$ \\
\hline
\end{tabular}

${ }^{1}$ Based on Wechsler Preschool and Primary Scale of Intelligence-Revised (WPPSI-R) test. ${ }^{2}$ Based on Stanford-Binet Intelligence Scales. 
weeks when she had a generalized tonic- clonic status epilepticus along with lactic acidemia (5.4 mmol/1; normal, 0.5- 2.2) The electroencephalogram (EEG) showed burst suppression pattern but seizures stopped and lactic acidemia resolved after administration of the same medications that her sister received. She had increased central and peripheral muscle tone. Computed tomography scan was normal. Thiamine (vitamin $\mathrm{B}_{1}$ ), pyridoxine, (vitamin $\mathrm{B}_{6}$ ) carbamazepine and phenytoin were continued throughout adulthood. Her psychomotor development was age appropriate apart from delayed speech development (Table). She remained seizure free until the age of 20 years when seizures reoccurred after a trial of simultaneous reduction of thiamine and pyridoxine. She continued to be seizure free until present upon pyridoxine $300 \mathrm{mg}$ once daily, carbamazepine 200 $\mathrm{mg}$ in the morning and $400 \mathrm{mg}$ in the evening.

At the age of 21 years her neurological examination shows an increased tone in the lower limbs and reflexes +3 . Systemic examination is normal. Her cognitive and adaptive skills are within the mild ID range (IQ 70-78) (details see Table).

Diagnosis of ATQ deficiency was confirmed in both sisters by elevated urinary $\alpha$-AASA $(7.1 \mathrm{mmol} / \mathrm{mol}$ creatinine and 1.4 $\mathrm{mmol} / \mathrm{mol}$ creatinine in Patient 1 and 2 respectively (normal< $0.5)$. Molecular analysis of the ATQ $(A L D H 7 A 1)$ gene revealed compound heterozygousity for two known pathogenic missense mutations, c. $1195 \mathrm{G}>\mathrm{C}$ (p. Glu399Gln) and c.1429G $>C(p$. Gly477Arg). ${ }^{1,6}$ The parents have not been tested.

\section{Discussion}

The outcome of treated patients with PDE / ATQ deficiency is variable. Despite seizure control, $75 \%$ of patients have developmental delay and intellectual disability (ID). ${ }^{7}$

In this report we demonstrate the intra-familial variability of intellectual long-term outcome. Both sisters have ID despite excellent seizure control. Although they share the same environment, type and onset of treatment, and ALDH7Al mutations, they differ in their degrees of ID. The older sister is not able to live unassisted and meets criteria for moderate ID (IQ 35-55). The younger sister is able to live independently and work, and meets criteria for mild ID (IQ = 70-78). As in other patients described in the literature ${ }^{8,9}$ language development is affected in both patients. There are a few reports in the literature describing different outcomes in siblings with PDE. Ulvi et al, $2002^{10}$ reported two sisters with PDE, one with mild intellectual disability at the age of eight years and the other with normal development at the age of one year. The course of the treatment was different between the two sisters and the younger sister still too young to predict long term intellectual development. Furthermore, in a series of 63 patients, ten families with multiple cases are reported with different clinical outcomes ranging from normal development to various degrees of intellectual disability. ${ }^{7}$ While most of them had been started at different ages with pyridoxine treatment, the observation in our patients demonstrate that even despite early start of treatment in both patients, the outcomes may be variable.

It has been suggested that the earlier the onset of clinical seizures and the longer the delay in diagnosis and initiation of treatment, the worse is the prognosis for cognitive function. $7,8,11$ On the other hand, patients treated as early as in the neonatal period had developmental delay and intellectual disability, whereas other patients with prolonged status epilepticus and later diagnosis had a normal IQ.12 Prenatal treatment with high dose pyridoxine followed by postnatal treatment did not prevent poor cognitive outcome in two affected offspring, ${ }^{13}$ while Bok et al, $2010^{14}$ reported good developmental outcome after prenatal treatment in three children from two Dutch families.

In our patients the different age of seizure onset may be related to the outcomes. The older sister, who is more severely affected, had an onset of clinical seizures in the neonatal period, whereas in the milder affected younger sister seizure onset was at six weeks. In both siblings, treatment with vitamin $\mathrm{B}_{6}$ was initiated at the time of clinical seizure onset, although PDE was not diagnosed until adulthood in both of them.

Although both sisters have increased urinary $\alpha$-AASA excretion, the more affected older sister had a higher level, compared to her younger, less affected sister. This is consistent with the observation of Mills et al $2010^{15}$ who reported three cases that had the highest $\alpha$-AASA levels of their cohort and had the severest clinical phenotype. However, whether there is a significant correlation between biochemical and clinical phenotypes remains unclear. Our patients are compound heterozygotes for two pathogenic missense mutations in the $A T Q$ (ALDH7A1) gene. Glu399Gln is the most common mutation observed in approximately $30 \%$ of mutated alleles. ${ }^{15}$ It affects binding of cofactor (pyridoxal phosphate) and is thought to have a severe impact on enzyme activity while the other mutation is Gly477Arg has an effect on dimer formation..$^{16}$

Both patients had lactic acidemia, which resolved after administration of pyridoxine and thiamine. The pathophysiology of PDE is determined by secondary pyridoxal-5'phosphate (PLP) deficiency due to chemical inactivation of PLP via a condensation reaction with Piperideine-6-Carboxylate (P6C). ${ }^{1}$ $\mathrm{P} 6 \mathrm{C}$ is in equilibrium with AASA, the product that accumulates in PDE. Pyridoxine is a precursor of PLP. Such chemically induced PLP deficiency has major consequences on a multitude of pyridoxine (PLP) dependent enzyme activities, including enzyme reactions facilitating activation of glycogenolysis. ${ }^{17}$ The observed lactic acidemia could therefore have been due to secondary PLP deficiency. Similar changes have been found in other patients with $A T Q$ deficiency. ${ }^{15}$

Despite the beneficial effect of pyridoxine on seizure activity, both patients have impaired cognitive outcome. While supplementation of pyridoxine aims at correction of PLP related pathophysiology, with the discovery of $A T Q$ deficiency as the underlying cause, it has become clear that PDE is an organic aciduria affecting lysine degradation in the brain. Consequently, reduction of accumulating, potentially neurotoxic organic acids (AASA and related compounds) via a lysine-restricted diet may become an option for additional treatment. ${ }^{5}$

Folinic acid responsiveness has been shown in a few cases ${ }^{18}$ and although the pathophysiological background is unclear, folinic acid supplementation might be another way to improve outcomes in patients with PDE/ATQ deficiency.

In summary our report highlights the variability of the natural history of the PDE/ ATQ deficiency even within the same family. International registries to accommodate more cases of PDE / $A T Q$ deficiency will lead to a better understanding of the natural history and will facilitate well designed treatment and outcome studies. 


\section{ACKNOWLEDGMENT}

The authors thank both patients and their family for making all their medical information available, Ms. Jennifer Lian for performing mutation analysis and Cynthia Davis for reviewing psychological assessments.

\section{REFERENCES}

1. Mills PB, Struys E, Jakobs C, et al. Mutations in antiquitin in individuals with pyridoxine-dependent seizures. Nat Med. 2006; 12(3):307-9.

2. Bankier A, Turner M, Hopkins IJ. Pyridoxine dependent seizures-a wider clinical spectrum. Arch Dis Child. 1983;58(6):415-8.

3. Goutieres F, Aicardi J. Atypical presentations of pyridoxinedependent seizures: a treatable cause of intractable epilepsy in infants. Ann Neurol. 1985;17(2):117-20.

4. Coker SB. Postneonatal vitamin B6-dependent epilepsy. Pediatrics. 1992;90(2 Pt 1):221-3.

5. Stockler S, Plecko B, Gospe SM, Jr., et al. Pyridoxine dependent epilepsy and antiquitin deficiency Clinical and molecular characteristics and recommendations for diagnosis, treatment and follow-up. Mol Genet Metab. 2011;104(1-2):48-60.

6. Bennett CL, Chen Y, Hahn S, Glass IA, et al. Prevalence of ALDH7A1 mutations in 18 North American pyridoxinedependent seizure (PDS) patients. Epilepsia. 2009;50(5): 1167-75.

7. Basura GJ, Hagland SP, Wiltse AM, et al. Clinical features and the management of pyridoxine-dependent and pyridoxineresponsive seizures: review of 63 North American cases submitted to a patient registry. Eur J Pediatr. 2009;168(6): 697-704.

8. Baxter P. Pyridoxine-dependent and pyridoxine-responsive seizures. Dev Med Child Neurol. 2001;43(6):416-20.
9. Gospe SM, Jr. Neonatal vitamin-responsive epileptic encephalopathies. Chang Gung Med J. 2010;33(1):1-12.

10. Ulvi H, Mungen B, Yakinci C, et al. Pyridoxine-dependent seizures: long-term follow-up of two cases with clinical and MRI findings, and pyridoxine treatment. J Trop Pediatr. 2002;48(5): 303-6.

11. Kluger G, Blank R, Paul K, et al. Pyridoxine-dependent epilepsy: normal outcome in a patient with late diagnosis after prolonged status epilepticus causing cortical blindness. Neuropediatrics. 2008;39(5):276-9.

12. Plecko B, Hikel C, Korenke GC, et al. Pipecolic acid as a diagnostic marker of pyridoxine-dependent epilepsy. Neuropediatrics. 2005;36(3):200-5.

13. Rankin PM, Harrison S, Chong WK, et al. Pyridoxine-dependent seizures: a family phenotype that leads to severe cognitive deficits, regardless of treatment regime. Dev Med Child Neurol. 2007; 49 (4): 300-5.

14. Bok LA, Been JV, Struys EA, et al. Antenatal treatment in two Dutch families with pyridoxine-dependent seizures. Eur J Pediatr. 2010;169(3):297-303

15. Mills PB, Footitt EJ, Mills KA, et al. Genotypic and phenotypic spectrum of pyridoxine-dependent epilepsy (ALDH7A1 deficiency). Brain. $2010 ; 133($ Pt 7):2148-59.

16. Scharer G, Brocker C, Vasiliou V, et al. The genotypic and phenotypic spectrum of pyridoxine-dependent epilepsy due to mutations in ALDH7A1. J Inherit Metab Dis. 2010;33(5):57181.

17. Newgard CB, Hwang PK, Fletterick RJ. The family of glycogen phosphorylases: structure and function. Crit Rev Biochem Mol Biol. 1989;24(1):69-99.

18. Gallagher RC, Van Hove JL, Scharer G, et al. Folinic acidresponsive seizures are identical to pyridoxine-dependent epilepsy. Ann Neurol. 2009;65(5):550-6. 